DOI: 10.1515/ausp-2015-0001

\title{
Stoic Virtues in Tertullian's Works and Their Relation to Cicero
}

\author{
Levente PAP \\ Sapientia Hungarian University of Transylvania (Miercurea Ciuc, Romania) \\ Department of Humanities \\ paplevente@sapientia.siculorum.ro
}

\begin{abstract}
Q. S. F. Tertullian was one of the most prominent writers and apologists of the early Christian Church. He had two important goals with his works: on the one hand, to introduce, according to the spirit of the age, the Christian teachings embedded in contemporary Roman culture; on the other hand, to highlight and emphasize the difference between the Christian teachings and the pagan ideas. This dichotomy is characteristic of his ethical teachings as well: while he emphasizes the importance of the Christian virtues, he does not forget about their philosophical background either. Tertullian demonstrably considered Stoic philosophy as the most acceptable philosophical thinking. Virtues have an important status in the teachings of the stoic body, just as they are a fundamental part of Christian ethics. The question arises whether Tertullian's views on virtues could have been influenced by his pagan Roman ancestor, M. T. Cicero, who also shared stoic doctrines. This is the question the present lecture tries to answer.
\end{abstract}

Keywords: virtues, Christianity, Tertullian, Cicero, ancient philosophy

Christianity, with its appearance, announced the coming of a new era in the history of the pagan Roman Empire. The new religion tried-at least, apparently - to separate itself from everything connected to the pagan culture (pageantry, lifestyle, literature, philosophy, etc.). We might think, based on the aforesaid, that the two cultures did not communicate with each other at all and no cultural transfer whatsoever could take place between them. However, this is not the case-as many have pointed it out before-and we shall demonstrate it in relation with a particular virtue, that of patientia, and two authors: the pagan Roman statesman and philosopher, M. T. Cicero, and Q. S. F. Tertullian, the Christian apologist.

Morals and virtues had an important role within the classic Greek-Roman culture. Together with the appearance of sophistry the topic of virtues became the focus of interest; that is when the different arguments began to be contrasted 
according to the principle of the dissoi logoi (Cf. Steiger 1993, 107-121). The first philosopher to truly deal with moral questions was Socrates; then Plato followed in his steps by being concerned not only with the philosophy of science but with ethical questions as well (Gosling 1983). According to Plato and his moral relativism, virtues are such values which, if accepted and internalized, will be beneficial and useful for those who have chosen to live according to them. ${ }^{1}$ Similarly to Plato, Aristotle sees virtues as values that are to be chosen and are useful at the same time. However, unlike Plato, he thinks that knowledge does not stand at the core of virtues; they are rather natural endowments that men are born with. To him, it is important to live a moral life because, according to him, virtuous deeds cause us pleasure, and pleasure is what we are looking for during our lives. In his Nicomachean Ethics he elaborated a catalogue of 12 virtues, among which the first one is courage, its passive form being hypomone, usually translated as patientia. An important element of this heroic virtue is magnanimitas (or megalopshychia, noble ambition at Aristotle). According to the Stoics, everything is moral which is in harmony with nature. They sustain Socrates's scientism in that they also emphasize the importance of oikeosis, in other words, the importance of learning about nature (Striker 1996, 183-195). Man possesses virtues only if he has knowledge as well; furthermore, one's reason can be taken away by strong emotions and passions (Marót 1999, 259).

M. T. Cicero's (stoic) philosophical conception is well known and has a vast literature (Cf. Graff 1963, Kerfeld 1972, Powel 1995). According to him, one of the greatest virtues is the one that has already been mentioned before i.e. magnanimitas, which incorporates the virtues of constantia, clementia and finally patientia which our paper focuses on (Tusc. 3.32, Part. Orat. 77, De oratore 2.143.). The virtue of magnanimitas has an important role in Stoic thinking, highlighting the peaceful acceptance of one's changing luck as well as endurance. According to Cicero, the starting point of every ethical question is oikeosis (Cf. Forschner 2008), the ability of the human soul to comply with the laws that rule in the universe, and with the necessities within men called fatum (Marót 1988). Fortitudo and patientia are like twins (together with magnificentia, fidentia and perseverentia). The Roman logographer defines these concepts in the following way:

The power of virtue then is twofold, for virtue is distinguished either by theory or by practice. For that which is called prudence, or shrewdness, or (if we must have the most dignified title for it) wisdom, is all theoretical. But that, which is praised as regulating the passions, and restraining the feelings of the mind, finds its exercise in practice. And its name is temperance. (Part. 77.) 
At the same time, patientia means that those who possess this virtue, are their own masters, they have potestas over themselves; therefore, it is not incidental that Cicero, in Tusculanae disputationes, says the following:

The whole, then, consists in this - that you should have command over yourself. I have already told you what kind of command this is; and by considering what is most consistent with patience, fortitude, and greatness of soul, a man not only restrains himself, but, somehow or other, mitigates even pain itself. (Tusc. II.53.)

Furthermore, self-control is what has a hold on and governs the animus, thus making suffering tolerable. ${ }^{2}$ In Tusculanae disputationes patientia accompanies the male virtue of courage. The interlocutors in Cicero's work say the following:

Will you act in a manner consistently with courage, and its attendants, greatness of soul, resolution, patience, and contempt for all worldly things? Can you hear yourself called a great man when you lie grovelling, dejected, and deploring your condition with a lamentable voice; no one would call you even a man while in such a condition. You must therefore either abandon all pretensions to courage, or else pain must be put out of the question. (Tusc. II. 32.)

Pain exists; the participants of the dialogue cannot and do not want to deny it; nevertheless, to endure suffering, one needs some kind of strength, the virtue of patientia:

I do not deny pain to be pain-for were that the case, in what would courage consist?-but I say it should be assuaged by patience, if there be such a thing as patience: if there be no such thing, why do we speak so in praise of philosophy? or why do we glory in its name? (Tusc. II. 33.)

In this sentence the speaker hints at the fact that in Greek-Roman culture the concept of patientia belonged primarily to the field of philosophy ${ }^{3}$ and it was of

2 Cf. Tusc. 5. 41. 74, 77, 80.

3 There is no mentioning of a godly embodiment of patientia in the Greek-Roman world either in archaeological or epigraphic, or in literary sources (Cf. Deubner 1909, 2127). The CIL VIII, 2728 talks about an inscription in which the triad of virtus, spes and patientia can be found. The author of the inscription is Nonius Datus (Takács 2013, 68-69), a famous Roman engineer from the $3^{\text {rd }}$ century AD (Cf. Février 1979). However, this triad was probably the result of the engineer's own combination as, while the cult of virtus and spes was well known in those times (Cf. Eisenhut 1974, 897; Latte1929, 1634), there is no data about a similar cult of patientia; furthermore, there are only two occasions when it appears as an attribute of gods (Cf. Carter 1902, 138). The propaganda of the imperial period, such as the Patientia Augusti, did not have 
an extremely great importance in philosophical thinking, as we implied earlier. Patientia was considered a very important human virtue by Cicero as well; the word patientia and its inflections appear more than 33 times in his works. Roman history provides us with numerous magna exempla for patientia controlling and governing the animus, and helping to endure pain, for example: Mucius Scaevola, M. Curtius, Regulus, ${ }^{4}$ the Decius or the Fabius. ${ }^{5}$ Cicero, as pater patriae, considered the fact that he managed to save the state from Catilina's raid, one of his greatest deeds; from that Catilina who, like a portentum, was only concerned with his own benefits and political ambition, rejecting and violating every moral and legal law. The first lines of the Oratio in Catilinam Prima became a proverb over the millenia and if one recalls these lines, he may observe the word patientia right at the beginning. ${ }^{6}$ The key element of his rhetorical question is: for how long Catilina, this enemy of the state, will abuse the patientia of the boni, the patientia which ensues from their magnanimitas, not from their fear. Patientia-as we could see earlieris only characteristic of brave, outstanding men. Thus, the word appears mainly in Cicero's philosophical works; he uses the word patientia in his speeches as well, but much less frequently. Interestingly, we can find it in four of his speeches uttered in judicial proceedings: in In Pisonem, Pro Milone, Orationes Philippicae, beside the previously mentioned In Catilinam. In almost all of these occassions, the term refers to the endless patience manifested towards the state's enemies by the honest Roman citizens and urban communities, together with Cicero, who are worried about the future of the state, the res publica Romana. ${ }^{7}$ Furthermore, another common trait of the speeches enumerated above is that the tyrannicidium, the enemy of the tyrannis or the autocrat is demonstrably retraceable to Stoic philosophy, just as the idea of patientia belongs to the Stoic thinking. We do not attempt to prove that Cicero was a Stoic; however, the arguments expressed earlier demonstrate that he had a Stoic attitude towards these two issues (Clark and Ruebel 1985). And, although he talks about two different meanings of patientia (on the one hand, the endurance of physical pain and suffering, which is characteristic of the brave, outstanding figures; on the other hand, the almost limitless patientia of the patient cives, the responsible civitas and the boni, the responsible statesmen who work hard on the safety of the state), they both have the same source, that is, Stoic philosophical thinking.

a great resonance either (Cf. Wallace-Hadrill 1981).

$4 \quad$ Fin. 5. 82-83.

5 In the Roman tradition patientia refers not only to the tough, manly, military endurance, but also to a virtue of the old youth (Aen. 9. 607-8.); it also appears with a not completely positive overtone like in some of the poems of Catullus; still, in the case of the great, outstanding men the word patientia always refers to a virtue (Kaster 2002, 142-143).

6 In Cat. 1. 1. Quo usque tandem abutere, Catilina, patientia nostra?

7 Pis. II. Ego Antonium conlegam cupidum provinciae, ulta in re publica molientem patientia atque obsequio meo mitigavi. 
Virtue was an important constituent of the pagan Roman world; similarly, the ability to choose good over bad, the arete or virtue is an important characteristic of a Christian's life as well, the lack of which prevents him from fulfilling the life worthy of a real Christian. Faith, hope and love are fundamental Christian virtues. Moreover, the Christian teaching highlights the importance of four other virtues described by cardinal attributes: prudentia, iustitia, temperantia and fortitudo. If we look at the Christian tradition, we may observe that the Old Testament does not say much about virtues, at least not as the abstract term for good deeds. The term arete occasionally appears, but with different meanings: perseverance (2Macc. 10,28; 15,12), piety (Wise 5,13), God's glory (Iz 42,8.12; 43,21; 63,7). The case is similar in the New Testament as well; the term arete does not have a unified meaning (the general conduct of the just, 2Pt 1,5: moral strength, 1,3: the power of God). We may find more accurate information about it in the so-called virtuecatalogues (Gal 5,22-26; Ef 5,25-32). This list of virtues contains: perseverance (perseverantia), peace (pax), faith (fides), fidelity (fidelitas), justice (iustitia), soundness, self-abnegation (abnegatio sui), meekness, patience (patientia) and religiousness (religiositas).

Virtues had an important role in the life of the early Christian church as well. Q. S. F. Tertullian is one of the most well-known figures of early Christian literature. Even though his personality and life divided the Christian public opinion for a long time, his works were of service to the-then quite young-Church. Virtues had an important role in Tertullian's conception as well. The source of his ethics and ethical thinking consists of his theological and eschatological views and character, his interpretation of the Bible, and last but not least, his Stoic way of thinking. The totality of these factors reveals an extremely various moral concept that is - at least partially - a Christian one, as long as its strength of validity is drawn from the rules of faith; but at the same time it also has non-Christian features, as long as it distances itself from the Christian moral concept to be found in the New Testament. Knowing that Tertullian had an impulsive and imperious nature, one may wonder why he was so interested in the virtue of endurance or patientia. Interestingly, the author was conscious of this discrepancy himself, thus he used this deficiency of his character as a captatio benevolentiae:

I Fully confess unto the Lord God that it has been rash enough, if not even impudent, in me to have dared compose a treatise on Patience, for practising which I am all unfit, being a man of no goodness; whereas it were becoming that such as have addressed themselves to the demonstration and commendation of some particular thing, should themselves first be conspicuous in the practice of that thing, and should regulate the constancy of their commonishing by the authority of their personal conduct, for fear their words blush at the deficiency of their deeds. And would that this 
'blushing' would bring a remedy, so that shame for not exhibiting that which we go to suggest to others should prove a tutorship into exhibiting it; except that the magnitude of some good things-just as of some ills too-is insupportable, so that only the grace of divine inspiration is effectual for attaining and practising them. For what is most good rests most with God; nor does any other than He who possesses it dispense it, as He deems meet to each. And so to discuss about that which it is not given one to enjoy, will be, as it were, a solace; after the manner of invalids, who since they are without health, know not how to be silent about its blessings. So I, most miserable, ever sick with the heats of impatience, must of necessity sigh after, and invoke, and persistently plead for, that health of patience which I possess not; while I recall to mind, and, in the contemplation of my own weakness, digest, the truth, that the good health of faith, and the soundness of the Lord's discipline, accrue not easily to any unless patience sit by his side. So is patience set over the things of God, that one can obey no precept, fulfil no work well-pleasing to the Lord, if estranged from it. (Pat. I. 1-6.)

According to Tertullian patientia is the first among the virtues that a Christian may resort to in his moral and religious life, and based on which he can live a life according to God. Putting away his apparent contempt toward the pagans, he mentions that their summa virtus is also patientia (I. 7.), although they live in spiritual darkness. Philosophers and philosophical schools, regardless of the differences in their approach or views, all study patientia:

The good of it, even they who live outside it, honour with the name of highest virtue. Philosophers indeed, who are accounted animals of some considerable wisdom, assign it so high a place that, while they are mutually at discord with the various fancies of their sects and rivalries of their sentiments, yet, having a community of regard for patience alone, to this one of their pursuits they have joined in granting peace: for it they conspire; for it they league; it, in their affectation of virtue, they unanimously pursue; concerning patience they exhibit all their ostentation of wisdom. (Pat. I.7.)

So in his writing Tertullian does not refer to the pietas or patientia that appears in different cultures and ideologies, but to philosophy and to those philosophers who dealt with this issue more extensively, namely the Stoics. It is evident that in the middle Stoic body and in that of the imperial period patientia did not have a secondary role anymore. Its coming to the fore had to do with the fact that it was associated with courage and magnanimitas. But why this particular virtue: patientia? And why did Tertullian consider it so important that he wrote an entire book on it? Beside the individual references mentioned above, it was 
also influential that Tertullian wanted to prove the existence of such topics or elements common in the Christian and the pagan thinking, which could show that pagan and Christian morality were closely related to each other. ${ }^{8}$ Patientia characterizes both the miles Romanus and the miles Christianus (Daniélou 1978, 28). The spiritual virtues gain their completion through the body. ${ }^{9}$ Patientia helps Christians to endure physical pain, which was very important in choosing martyrdom, especially for the early Christians of the first few centuries. As the author himself emphasizes: Si spiritus promptus, sed caro (sine patientia) infirma, ubi salus spiritus et carnis ipsius? Hence, God himself tells that the body must necessarily be strong to be able to endure all kinds of suffering. ${ }^{10}$ According to Tertullian the body becomes tolerant to all kinds of pain only with the help of patientia. He thought that martyrdom was the greatest honour for a Christian which, however, could only be reached through the high cultivation of patientia. In his interpretation patientia does not mean some kind of cynical stolidity, indolence, or dullness; on the contrary, it is a divine characteristic which manifested itself in God's act of creation and providence. Not only does the pagan Roman world have its magna exempla, but Christians also have their own role models; two of them are identified by Tertullian as being Isaiah and the martyr Saint Stephen. ${ }^{11}$ He creates a new triad: the Christian patientia, the pagan patientia and impatientia. A good example for the first one is God himself, because, on the one hand, he gave all the created goods to men in spite of the fact that they did not deserve it; and, on the other hand, he tolerated idolatry, the persecution of his worshipers and the sins of the pagan. Other examples of the Christian patientia are the great personalities of the Old Testament such as Abraham, then Jesus Christ himself, who demonstrated this virtue with his whole life; and last but not least, the Christian believers, the servi dei gave a good example of how one must endure torture and suffering. The pagan patientia is

8 Apol. 46. 2 Sed dum unicuique manifestatur veritas nostra, interim incredulitas, dum de bono sectae huius obducitur, quod usu[i] iam et de commercio innotuit, non utique divinum negotium existimat, et magis philosophiae genus. Eadem, inquit, et philosophi moment atque profitentur, innocentiam iustitiam patientiam sobrietatem pudicitiam.

$9 \quad$ Pat XIII. 6-7. Quod de uirtute animi uenit in carne perficitur: carnis patientia in persecutionibus denique proeliatur. Si fuga urgeat, incommoda fugae caro militat; si et carcer praeueniat, caro in uinculis, caro in ligno, caro in solo, et in illa paupertate lucis et in illa penuria mundi. Cum uero producitur ad experimentum felicitatis, ad occasionem secundae intinctionis, ad ipsum diuinae sedis ascensum, nulla plus illic quam patientia corporis.

10 Pat XIII. 8. At cum hoc dominus de carne dicit, infirmam pronuntians, quid ei firmandae opus sit ostendit, patientia scilicet, aduersus omnem subuertendae fidei uel puniendae paraturam, ut uerbera, ut ignem, ut crucem bestias gladium constantissime toleret quae prophetae, quae apostoli sustinendo uicerunt.

11 Pat XIV. 1. His patientiae uiribus secatur Esaias et de domino non tacet, lapidatur Stephanus et ueniam hostibus suis postulat. 
represented by the philosophers. Examples of impatientia include Satan, who rebelled against God because he could not accept that God gave the created world to men; further examples are Adam and Eve, Cain and the people of Israel who dared to rebel against God, their benefactor, and turn to idols.

Still, the closest example of patientia for the Christians is Jesus Christ, who suffered death. Thus, the homo patiens is characterized by the strength to accept suffering (sickness, starvation) or even death for the sake of Christ and his faith. Tertullian also says that patientia can even cause delight for its bearer if somebody attempts at disturbing him or wants to cause some damage to him but he fails to do so. Then, the suffering of the offender gives the patient man some kind of gratification. However, the Christian patientia is in no way connected to hatred; its prototype is the divine patientia, the patient suffering of Christ for our sins, which should characterize every Christian, as the virtue of the good (boni) is patientia, the lack of which makes Christian love impossible to sustain, since this virtue gives reason and quality for caritas. ${ }^{12}$ From the foregoing it is clear that Tertullian's view on patientia was strongly influenced by the philosophical concept of apatheia. Even though the exact origin of this concept is still unclarified, it is certain that Stoic philosophy used it in this context, as arete or virtue which is knowledge; consequently, we must avoid any irrational urge (pathos) which might influence our reason; for, as only our virtues can make us truly happy, pathos would only keep us from our pursuit of happiness. The overcoming of the perturbatio ${ }^{13}$ animi was important for Cicero as well, and it could be reached through the tranquillitas animi (Brachtendorf 1997).

Based on the aforesaid we can conclude that Tertullian, the Christian apologist considered patientia an extremely important virtue even though he did not possess it himself. He knew about its Christian roots, but still, he did not build his treatise about the Christian virtue of patience on that knowledge. He rather based his reasoning on Stoic ideas which he used to conceptualize the Christian virtue, so he was in favour of the pagan philosophical thinking instead of the Christian one. In this he follows in the footsteps of Cicero, who was also preoccupied with this matter, and his approach was built on no other philosphical ground (cynical or peripathetic) than the Stoic one. He wrote about the nature of patientia in his philosophical tracts, and he treated the concept with distinguished attention in his speeches (it could not appear anywhere and in any textual context). As shown before, the similarities in the way of thinking of the two authors are not restricted to this particular matter. Patientia is one of the cardinal virtues for both of them, one that is possessed only by the good, the boni who are able to endure the physical and spiritual sufferings caused by the evil and thus their

12 Cf. Pat. 1. 15. 12. Pud. 1.

13 It can also be interpreted as the equivalent of the Christian passio, since the concept, as used by Tertullian, was unknown in Cicero's time. 
moral conduct conquers over the evil. In the discourse on this one particular virtue we find that an intercultural transfer did exist between such worlds that, at first view, seem not to have been in contact with each other; but, due to their rich cultural heritage, they could never part completely; the two worlds being that of the Christian culture and the ancient, pagan Greek-Roman culture.

\section{Works cited}

Brachtendorf, Johannes. 1997. Cicero and Augustine on the Passions. Revue des Etudes Augustiniennes 43: 289-308.

Clark, Mark Edward and Ruebel, S. James. 1985. Philosphy and Rhetoric in Cicero's Pro Milone. Rheinisches Museum für Philologie 128: 57-72.

Carter, Jesse Benedict. 1902. Epitheta deorum quae apud poetas latinos leguntur. Lipsiae: Teubner.

Daniélou, Jean. 1978. Les origines du christianisme Latin. Paris: Cerf.

Deubner, Ludwig. 1909. Personifikationen. Ausführliches Lexikon der griechischen und römischen Mythologie. Berlin: Teubner.

Eisenhut, W. Virtus. 1974. RE Suppl. XIV. Stuttgart: J. B. Metzler.

Février, P.-A. 1979. L armée romain et la construction des aqueducs. Dossier de l'archeologie 38: 88-93.

Forschner, Maximilian. 2008. Oikeiosis. Die stoische Theorie der Selbstaneignung. In Stoizismus in der europäischen Philosophie, Literatur, Kunst und Politik, eds. Neumeyr B. et alii, 169-192. Berlin-New York: Walter de Gruyter. Vol. 1.

Gosling, J. C. B. 1983. Plato. London-Boston: Routledge.

Graff, Jürgen. 1963. Ciceros Selbstauffassung. Heidelberg: C. Winter.

Kaster, Robert A. 2002. The Taxonomy of Patience or when is patientia a virtue? Classical Philology 97: 133-144.

Kerfeld, G. B. 1972. Cicero and Stoic Ethics. In Cicero and Virgil. Studies in Honour of Harold Hunt, ed. Martyn, J. R. C., 60-74. Amsterdam: Hakkert.

Latte, K. Spes. 1929. RE III A6. Stuttgart: J. B. Metzler.

Marót Miklós. 1988. Néhány szó a sztoikus esztétikáról. [A Few Words about Stoic Aesthetics.] In Múalkotás-esztétikum-közönség az antikvitásban [Artwork Aesthetics - Audience in the Antiquity], ed. László Havas, 28-38. Debrecen: KLTE.

—. 1999. Ókori filozófia története. [The History of Ancient Philosophy.] In Bevezetés az ókortudományba II. [Introduction into the Classical Studies II.], eds. László Havas and Imre Tegyey, 223-270. Debrecen: Kossuth Egyetemi Kiadó.

Powell, J. G. F. 1995. Cicero's Philosophical Works and their Background. In Cicero the Philosopher. Twelwe Papers, ed. Powell, J. G. F., 1-35. Oxford: Calderon.

Steiger Kornél. 1993. A szofista filozófia. [Sophist Philosophy.] Budapest: Atlantisz. 
Striker, Gisela. 1996. The Role of Oikeosis in Stoic Ethics. In Essays on Hellenistic Epistemology and Ethics, ed. Striker, Gisela, 183-195. Cambridge: CUP.

Takács Levente. 2013. The Social Status of Roman Land Surveyors. Budapest: Kódex.

Telwall, S. (transl.). 1866-72. Of Patience. In The Ante-Nicene Christian Library: Translations of the Fathers down to A.D. 32, eds. Roberts, A. and Donaldson, J., 205-230. Edinburgh: T\&T Clark. Vol. XI.

Tertullien. 1984. De la patience. Fredouille Jean-Claude (trad. ed.). Paris: Les éditions du CERF.

Valente, Milton P. 1956. L'éthique stoïcienne chez Cicéron. Paris: Librairie SaintPaul.

Wallace-Hadrill, Andrew. 1981. The Emperor and His Virtues. Historia: Zeitschrift für Alte Geschichte 30: 298-323.

Yonge, C. D. (transl.). 1877. Cicero's Tusculan Disputations. New York: Harper \& Brothers. 